\title{
Analysis of postmenopausal osteoporosis in primary care in the canary islands Spain (ESTOPMAPCA project)
}

Olmo Quintana $\mathrm{V}^{1 *}$, Ramírez $\mathrm{T}^{2}$, García Santana $\mathrm{MI}^{3}$, Martin Torres $\mathrm{M}^{1}$, González Núñez J ${ }^{4}$, Orero González $\mathrm{A}^{4}$, Santos Sancho J ${ }^{5}$, Martínez Hernández $\mathrm{D}^{5}$, Alonso Bilbao $\mathrm{JL}^{6}$ and Sosa Henriquez $\mathrm{M}^{7}$

${ }^{1}$ Farmacéutico de Atención Primaria- Presidente CEIm, Spain

${ }^{2}$ Unidad de Investigación CHUIMI, Spain

${ }^{3}$ Enfermera Complejo Hospitalario Materno Infantil, Spain

${ }^{4}$ SEFYP, Spain

${ }^{5}$ Dpto. Medicina Preventiva y Salud Pública UCM, Spain

${ }^{6}$ Unidad de Investigación Gerencia AP, Spain

${ }^{7}$ Unidad Metabólica Osea CHUIMI, Spain

\begin{abstract}
Summary: Sosiosanitario ESTOPMAPCA study, is a geriatric research program to establish the map of the first level of care in these patients, in order to propose strategies to improve the efficiency and quality of care.

Objetives: 1) To assist decision making at all levels: prevention, diagnosis, treatment and monitoring, 2) To facilitate clinical reasoning, 3) Develop a reasoned guide, to avoid problems of RAM, especially in patients with postmenopausal osteoporosis (OPM) pluripatológicas and polymedicated.

Methodology: Descriptive, transversal, through structured questionnaire, conducted in a single day, through structured and validated based on data from the last query from a patient with (OPM) questionnaire study. AP Canary field. sampling error of $\pm 4.4 \%$ and a confidence level of $95.5 \%$, assuming $\mathrm{p}=\mathrm{q}=50 \%$.

Results: 156 responded to the survey care physicians (13.39\%), each doctor sees an average of 36.8 days patients, 4 of 10 OPM diagnostic x-rays, and 30\% referred to a specialist MF, 3 of 10 OPM respond associate with arthrosis diagnosis and Lumbargia in 8 out of 10 drug treatment performed (Alendronate and calcium), $8-9$ in $10 \mathrm{MF}$ recommend dietary measures and regular exercise. $35.6 \%$ believe that failure is $15-20 \%, 33.8 \%$ more than 7 patients take drugs, cost effectiveness is the selection criteria for treatment (79.8\%).
\end{abstract}

Conclusions: The results obtained suggest the need to improve the knowledge and hone the skills of PHC physicians in patient care with OPM.

\section{Introduction}

Primary Health Care (PHC) is the first point of contact for patients with health care and is key for the suspicion of osteoporosis in postmenopausal women (OPM), as well as for their diagnostic and therapeutic approach and the establishment of strategies for the prevention of fracture risk. It is also responsible for the correct referral of patients to Specialized Care (AE) [1].

Osteoporosis is the most frequent bone metabolic disease, it represents a serious public health problem in the whole world and, in particular, in Spain, It has a high morbidity and mortality in public health, and on the quality of life that fracturespose together to a high consumption of human resources, economic, technical and health expenditure $[2,3]$. Osteoporosisa is especially prevalent among postmenopausal women.

It is defined as a skeletal systemic disease characterized by low bone mass and by the deterioration of the microarchitecture of bone tissue with the consequent increase in bone fragility and susceptibility to fracture $[4,5]$. Shortly afterwards, a practical classification was established, based on the values of bone densitometry, and criteria for normality, osteopenia and osteoporosis were defined according to the variable T-score.
Hip and spine fractures are particularly associated with high morbidity, disability (often requiring chronic care) and mortality in this population.

It is estimated that there are more than 200 million patients with osteoporosis in the world6. The prevalence of osteoporosis increases with age and population aging [4]. In Spain, it is estimated that osteoporosis affects $35 \%$ of women over 50 years of age, $52 \%$ of those who are over 70 years old and $60 \%$ of those who are 80 or older. In 2002, osteoporosis affected some 3,700,000 people in Spain, of whom $2,700,000$ were women7. Probably the underdiagnosis exceeds $50 \%$ and it is possible that only $1 / 4$ part of the patients receive the appropriate treatment. In men, the estimated prevalence is $8 \%$ in people over 50

${ }^{\star}$ Correspondence to: Vicente Olmo Quintana, Primary Care Management Las Palmas, AP Pharmacy Service, C/Luis Doreste Silva 34-40, C.S CanalejasCanary Islands Health Service, Spain, Tel: 928308485; E-mail: volmqui@ gobiernodecanarias.org

Key words: postmenopausal osteoporosis, efficiency, quality of care

Received: December 06, 2018 Accepted: December 23, 2018; Published: December 28, 2018 
years of age. Of these, only less than $30 \%$ of patients are diagnosed with osteoporosis, and less than $10 \%$ receive treatment [8].

When considering the epidemiology of osteoporosis, it is necessary to consider osteoporosis without fracture, which is diagnosed by bone densitometry (DXA) [9], and osteoporosis with fracture, that is, established osteoporosis. Among the various technologies available, the DXA technique it is the optimal procedure to estimate the risk of fracture (evidence 1A).

The emergence of the FRAX tool [10-12] and the better knowledge of osteoporosis and the different treatments, means that we must rethink whether they persist or modify the indications of whom to treat, for how long, with what drug, etc [2].

The EVOS (European Vertebral Osteoporosis Survival) study shows that the prevalence of vertebral fracture increases progressively with age until it reaches $25 \%$ or more after 75 years of age [13]. The AFOE Study (Act of Osteoporotic Fracture in Spain, 2003) indicates an incidence of 7.2 hip fractures per-1,000 people over 60 years [14], the incidence in the over 75 years is 4 times higher. In relation to radio fractures, the incidence is 6.6 per- 1,000 people over 60 , of which more than $2 / 3$ are women.

Therefore, it can be said that postmenopausal osteoporosis is a disease of great clinical relevance, which increases with longevity and sedentary lifestyle and is complicated by fractures that are located mainly in the hip spine, and forearms [15], which in some cases, it requires long hospital stays [16], sometimes longer than other serious diseases, such as diabetes, cardiovascular diseases.

Moderate exercise is one of the most recommended universal measures, at least 30 minutes, 5 days a week, along with an adequate diet [17]. Smoking is a risk factor, which is associated with loss of bone mass 16, and which, therefore, must be eliminated.

Both calcium and vitamin D in people older than 63 years reduce the risk of suffering fractures of this type, so the joint supplement of the diet is recommended with the total daily intake of $1.2 \mathrm{~g} /$ day of calcium and 800 Vitamin D16 UI.

Bolland et al. [18], in a meta-analysis conducted in 2011, studied the effect of personal calcium supplement on cardiovascular risk in women, with and without vitamin D supplementation. This type of treatment moderately increases the risk of cardiovascular accidents, especially the acute myocardial infarction.

An important problem in these patients with osteoporosis is the adherence to treatment with a high percentage of dropouts during the first year. The consecuenti Principio del formulariomost notable is the lack of therapeutic response [19].

The treatments can be non-pharmacological and/or pharmacological, which in general have few side effects that are considered serious, with bisphosphonates being considered the first choice in our environment. For this reason, the number of patients treated with a drug for osteoporosis has increased in recent years [9].

For the design and approach of the study, the most relevant works published in scientific journals were taken into account (original articles - individual clinical studies and meta-analysis and review) as the most important Clinical Practice Guidelines (CPG) and other documents of interest such as the Clinical Practice Guideline of the Spanish Society of Bone Research and Mineral Metabolism (SEIOMM) (2015) [9], the Consensus of the Spanish Society of Rheumatology (SER) (2011) [20], the Guide of Good Clinical Practice sponsored by the Collegial Medical Organization (OMC) [8] and the Ministry of Health, Social Policy and Equality (MSPSI) (2011), the Guide to Clinical Practice developed by this last organization (2010), SECOT 2010 Guide on Osteoporosis of the SIGN [22], The review of the NOF [23], AACE 2010 [24], NAMS 2010 [25], NICE 2011 [26].

\section{The objectives of this study are}

- To determine the day-to-day of primary care for patients with postmenopausal osteoporosis in the Canary Islands. To help decision-making at all levels: prevention, diagnosis, treatment and follow-up.

- To facilitate clinical reasoning.

- Prepare a reasoned guide that avoids AMR problems, especially in patients with polypathic and polymedicated OPM.

\section{Methodology}

Study in a multicentric, autonomic, observational, cross-sectional population, using a structured questionnaire, based on the data of the last consultation made by the family doctor surveyed and whose reason for consultation was postmenopausal osteoporosis (OPM), in the field of Primary Health Care of the Canary Islands.

OPM has an estimated prevalence in Spain for 1 out of every 3 women over 50, which means a universe of about 2,700,000 women. In our Autonomous Community there are 354,150 women over 50 years of age according to ISTAC data as of December 2012. The number of Family Physicians practicing in APS in our community is 1172 physicians with the following distribution by health area [Gran Canaria 483; Fuerteventura 54; Lanzarote 79; Tenerife 482; La Palma 49; Gomera 17, Hierro 8], with 30 to 40 daily consultations each doctor. The average estimate of patients who consult OPM daily for each doctor in Primary Health Care Centers (CAPS) is 1 to 3.

On the other hand, given that family doctors in the CAPS attend a woman with OPM daily, a priori, there must be a good memory from the doctor in relation to the last consultation made by a patient, given the immediacy of the case, and a low memory bias.

The expected response rate in this type of study is $15-20 \%$, so the initial calculation was estimated in the proportional distribution of a total of 1172 questionnaires among as many family doctors, with a minimum of 176 valid questionnaires (sample error of $\pm 4.4 \%$ and a confidence level of $95.5 \%$, assuming $\mathrm{p}=\mathrm{q}=50 \%$ ).

After the probation by the CEIm The anonymous questionnaire was sent to the addresses of areas and Management of PA, with six groups of questions and 23 total questions one for each doctor, requesting that they be distributed to all the health centers of the Autonomous Community of the Canary Islands, the data collection was done throughout the Canary archipelago on June 5, 2016. The answers were returned to the authors from the health centers.

Data coding was carried out with the SPSS (Statistical Package for the Social Science) v 20.0 program with the appropriate licenses.

For the study of qualitative variables, these are described with the frequency distribution, and for the comparison of qualitative variables, the Chi-square test is used. 


\section{Results}

\section{General aspect}

Of the 1171 GPs invited to participate in the study, a total of 156 responded to the questionnaire, representing $13.32 \%$ of the total sample, 93 of the questionnaires came from the province of Las Palmas and 61 from the province of Tenerife, no response was received from the islands of La Gomera, Hierro, Lanzarote.

The distribution of physicians by sex was similar between $50 \%$ males and $49.4 \%$ females, with an average age of 52.22 years (95\% CI 50.8-53.64 SD 8.63), the mean number of years of exercise was 24.06 (95\% CI 22.65-25.48 SD 8.91) (Figure 1). Majority with urban exercise (67.8\%), each physician attended on average 36.8 patients $(95 \% \mathrm{CI}$ $35.35-38.36$ DS 9.65) a total of 5,521 patients of which $1,752(31.73 \%)$, were administrative issues (Low, renewal of PTU...) 25.3 (68.27\%) consultations were by process clinical Each doctor responds to see 1.52 patients with OPM (95\% CI 1.20-1.85). $64.7 \%$ of the patients were pensioners. Table 1, shows the characteristics of patients with OPS, attended on the day of the study.

\section{Reason for consultation}

Only $12.2 \%$ (19) patients were new diagnoses (DX), in $84.2 \%$ of the cases a detrometry was performed, to the rest of the patients their
DX was performed through X-rays 90 (57.7\%), FRAX 36 (23.1\%), Biochemical Markers 12 (7.7\%), 39.1\% of the Dx patients had been referred to the second level of care, and $23.7 \%$ of the cases did not answer this question. patients (70) referred to specialized care, $17.9 \%$ went to the rheumatologist, $12.2 \%$ to a traumatologist, $7.1 \%$ to gynecology, and to the bone metabolic unit (BMU), 6.4\%.

In the case of not being a new DX, the Treatment was established by the family doctor in $39.7 \%$, and in $45.5 \%$ by a specialist, 96 physicians answer affirmatively that patients with OPM have other diagnoses. Figure 2 shows the associated diagnoses that most frequently present patients with OPM in this study, when asked if they remembered if the last patient with OPM had risk of fracture $70.5 \%$ (110) of the doctors answered affirmatively (Figure 3 ). The risks associated with the appearance of fractures, which suffered from the study patients, are related.

\section{Comorbidities}

The doctors responded that the patients presented other comorbidities such as osteoarthritis in $45.5 \%$ (71) of the Responses; Dorsalgias in $32.7 \%$ (51) of the patients with OPM, and 9.0\% (14) Rheumatoid Arthritis (RA). In addition, patients presented other underlying pathologies such as: Depression in $23.1 \%$ of patients, Anxiety in $34.6 \%$, Dementia in $6.4 \%$, HBP in $57.7 \%$, Diabetes in $25.6 \%$.

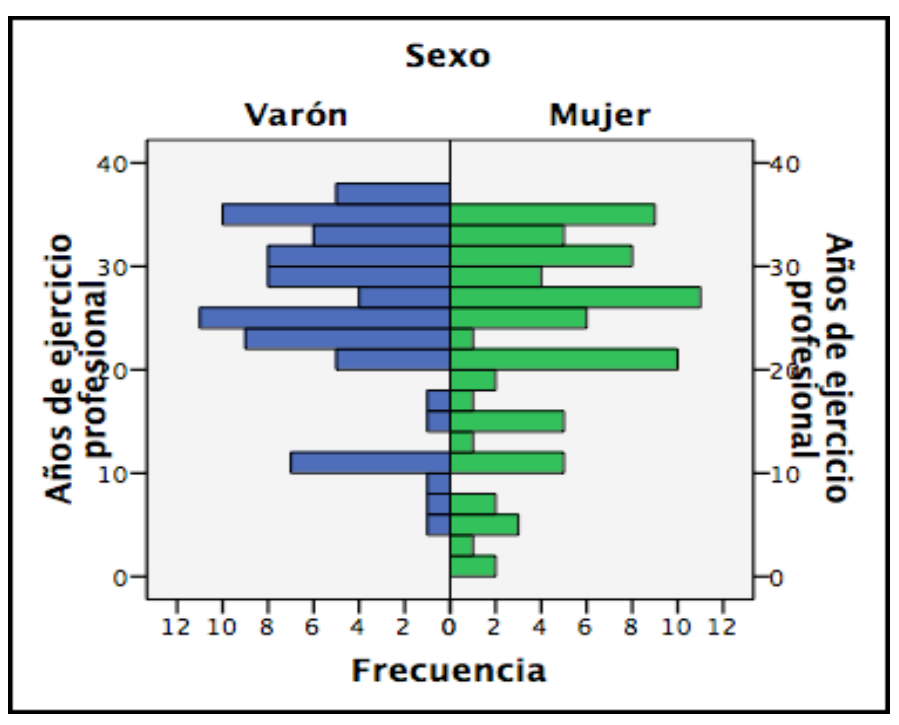

Figure 1. Distribution of years of professional practice according to sex

Table 1. Statistical data related to the last query

\begin{tabular}{|c|c|c|c|c|c|c|c|}
\hline & $\begin{array}{l}\text { Remember how many } \\
\text { patients were seen in } \\
\text { the clinic today? }\end{array}$ & $\begin{array}{c}\text { Of the patients } \\
\text { attended today, how } \\
\text { many have been for } \\
\text { administrative issues? }\end{array}$ & $\begin{array}{c}\text { Of the patients treated } \\
\text { today, how many } \\
\text { have been clinically } \\
\text { treated }<?\end{array}$ & $\begin{array}{c}\text { Of the patients treated } \\
\text { today, how many } \\
\text { have been to present } \\
\text { OPM? }\end{array}$ & age last query & Weight last query & Height in $\mathrm{cm}$ \\
\hline N-Válidos & 150 & 153 & 153 & 149 & 153 & 146 & 140 \\
\hline Perdidos & 6 & 3 & 3 & 7 & 3 & 10 & 16 \\
\hline Media & 36,81 & 11,23 & 25,3 & 1,52 & 67,1 & 69,21 & 155 \\
\hline Error típ. de media & 0,788 & 0,603 & 0,738 & 0,165 & 0,885 & 1,089 & 2,262 \\
\hline Mediana & 38 & 10 & 25 & 1 & 68 & 68 & 160 \\
\hline Desv. típ. & 9,657 & 7,456 & 9,123 & 2,012 & 10,944 & 13,157 & 26,763 \\
\hline Varianza & 93,258 & 55,599 & 83,225 & 4,048 & $1,19,765$ & $1,73,116$ & $7,16,245$ \\
\hline Rango & 59 & 38 & 65 & 18 & 59 & 101 & 179 \\
\hline Mínimo & 1 & 0 & 1 & 0 & 37 & 47 & 1 \\
\hline Máximo & 60 & 38 & 66 & 18 & 96 & 148 & 180 \\
\hline
\end{tabular}

Characteristics of Patients with a diagnosis of OPM, which reminds the professional and who went to the office on the day of the study. 


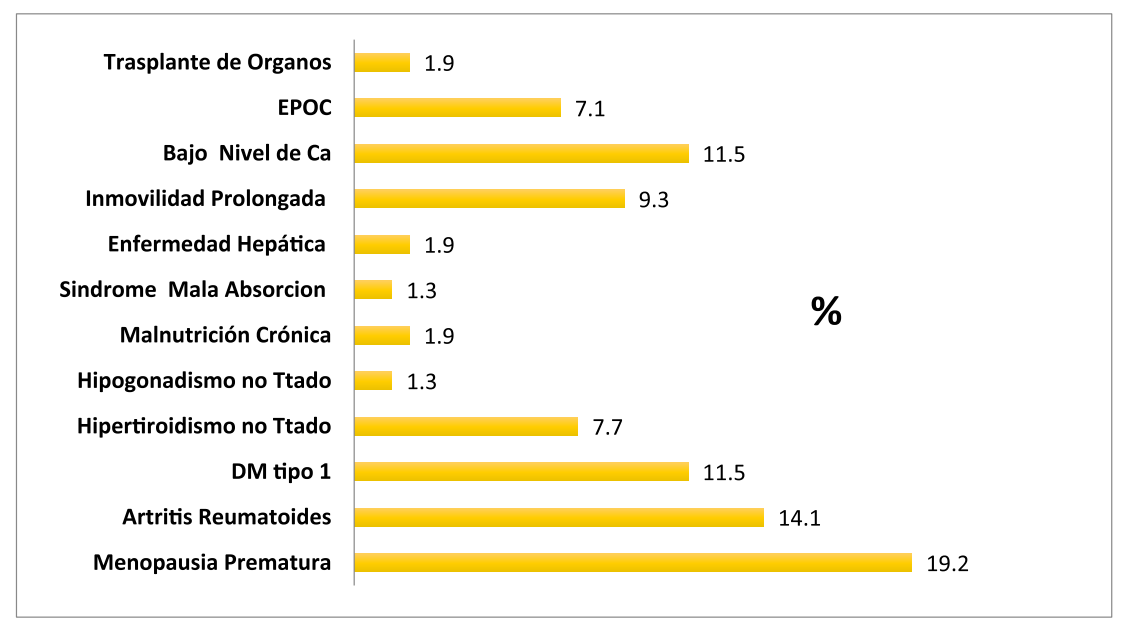

Figure 2. Diagnostics associated with OPM according to participating physicians

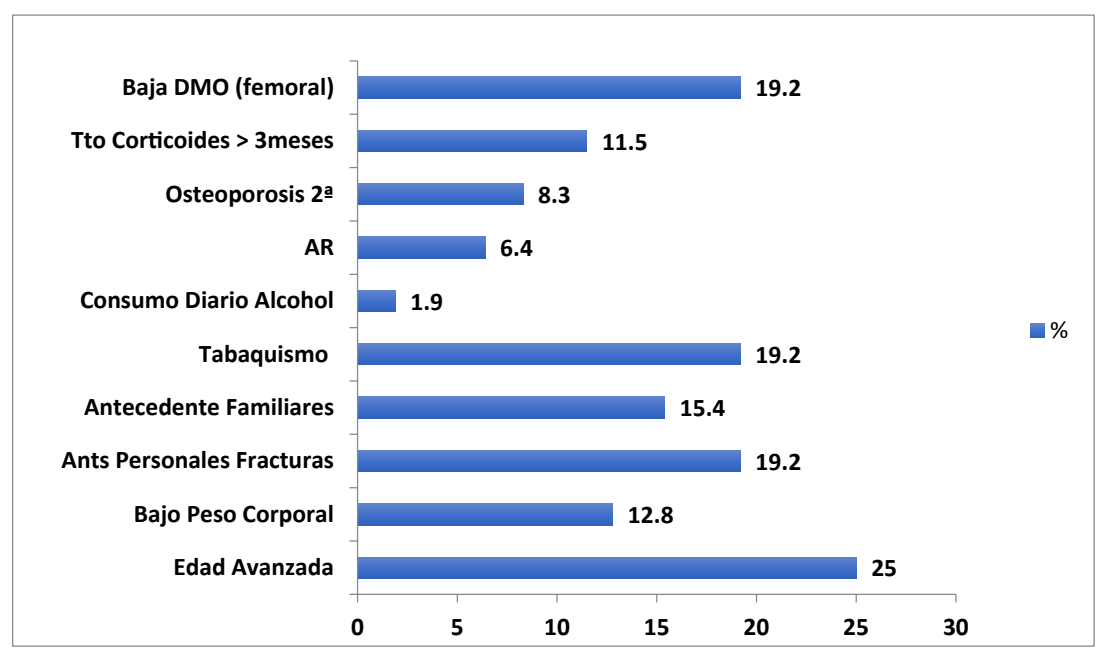

Figure 3. Factors associated with the risk of fractures in patients with OPM, who come to the office on the day of the study

\%, Obesity in $17.3 \%$ Recommendations on healthy living habits $92.5 \%$ (145) of the doctors participating in the study, made recommendations on healthy lifestyles to their patients with OPM, regardless of the province in that the doctor exercises, Table 2 shows the valid response received Recommendations on pharmacological treatments: $84.6 \%$ of doctors (132), indicate pharmacological treatment with the following criteria eln 61, \%\% Calcium supplement indicated and vitamin D; Hormone Replacement Therapy (HRT) in 1.3\%; Alendronic Ac was prescribed in $37.2 \%$, Risendronic Ac in $16.3 \%$; Ibandronico at $7.1 \%$; Raloxifene in 3.8\%; Bezedoxifene 2.6\%, others mainly denosumab $2.6 \%$.

In $51.9 \%$ of the cases, additional treatments were instituted against pain as an associated symptom; practically only in $15.2 \%$ of the patients, pharmacological treatments were instituted, aimed at reducing the risk of fracture, while $44.5 \%$ of the professionals recognize that these patients with OPM will be implanted/modified the treatment for their comorbidities, the day of the study The degree of polymedication (considering this as taking more than 5 drugs, including OPM treatments) in our study stood at $56.2 \%$ of the surveys that were considered valid.

General criteria in the management and follow-up of the OPMEn regarding the degree of non-compliance by patients with OPM, only $20 \%$ of the interviewees considered that this was less than $10 \%$, being between $20-40 \%$ non-compliance for the Most of the respondents, $66.8 \%$ of professionals usually take into account or take into account the costs derived from the introduction of pharmacological treatments, with the cost-effectiveness parameter being the majority criterion (80\%) used by the participating physicians. When selecting a treatment, the price has a secondary value. As to what criterion the professional has in mind when dealing with the management of OPM, it varies depending on whether or not it is a center where the practitioner develops his professional activity, such that the CPGs are used more in non-teaching centers, Table 3 .

\section{Discussion}

Osteoporosis is the most frequent bone metabolic disease and represents a serious public health problem worldwide $[9,21,27]$ and, in particular, in Spain [9]. osteoporosis is an asymptomatic disease difficult to diagnose in the absence of a fracture.

The objective of this study was to know the characteristics of primary care for patients with postmenopausal osteoporosis by family physicians, which allows defining the diagnostic, preventive and therapeutic, pharmacological and non-pharmacological profile, and, starting from Here, establish criteria to design a better allocation of resources, improving efficiency. 
Table 2. Response given by professionals in relation to giving recommendations on life habits, according to provinces

\begin{tabular}{|c|c|c|c|c|}
\hline & & \multicolumn{3}{|c|}{ Provincia } \\
\hline & & Las Palmas & S/C Tenerife & Total \\
\hline \multirow{2}{*}{ Medidas Dieteticas } & Recuento & 74 & 53 & 127 \\
\hline & $\%$ dento de Provincia & $82.20 \%$ & $86.90 \%$ & \\
\hline \multirow{2}{*}{ Ejercicio fisico regular } & Recuento & 79 & 56 & 135 \\
\hline & $\%$ dento de Provincia & $87.80 \%$ & $91.80 \%$ & \\
\hline \multirow[b]{2}{*}{ Prevencion de habitos toxicos } & Recuento & 42 & 36 & 78 \\
\hline & $\%$ dento de Provincia & $46.70 \%$ & $59.00 \%$ & \\
\hline \multirow{2}{*}{ Promocion de habitos saludables } & Recuento & 61 & 40 & 101 \\
\hline & $\%$ dento de Provincia & $67.80 \%$ & $65.60 \%$ & \\
\hline \multirow{2}{*}{ Realizo trataniento farmacologico? } & Recuento & 78 & 52 & 130 \\
\hline & $\%$ dento de Provincia & $86.70 \%$ & $85.20 \%$ & \\
\hline \multirow{2}{*}{ Suplemento de calcio y vitamina D } & Recuento & 56 & 40 & 96 \\
\hline & $\%$ dento de Provincia & $62.20 \%$ & $65.60 \%$ & \\
\hline Total & Recuento & 90 & 61 & 151 \\
\hline
\end{tabular}

Los porcentajes y los totales se basen en los encuestados.

Table 3. Criteria followed by the professionals when dealing with the management of the OPM, according to the seo or non-teaching professional practice center

\begin{tabular}{|c|c|c|c|c|}
\hline & & Docente & No docente & Total \\
\hline \multirow{2}{*}{ Guias de Practica Clinica } & Recuento & 38 & 49 & 87 \\
\hline & $\%$ dento de Provincia & $71.70 \%$ & $80.30 \%$ & \\
\hline \multirow{2}{*}{ Protocoloes de Actuacion } & Recuento & 25 & 24 & 49 \\
\hline & $\%$ dento de Provincia & $47.20 \%$ & $39.30 \%$ & \\
\hline \multirow{2}{*}{ Consensos/Documentos de Sociedades Cientificas } & Recuento & 17 & 18 & 38 \\
\hline & $\%$ dento de Provincia & $32.10 \%$ & $29.50 \%$ & \\
\hline \multirow{2}{*}{ Recomendaciones del especialista } & Recuento & 16 & 17 & 33 \\
\hline & $\%$ dento de Provincia & $30.20 \%$ & $27.90 \%$ & \\
\hline \multirow{2}{*}{ Recomendaciones del Farmaceutico de Area } & Recuento & 1 & 2 & 3 \\
\hline & $\%$ dento de Provincia & $1.90 \%$ & $3.30 \%$ & \\
\hline Total & Recuento & 53 & 61 & 114 \\
\hline
\end{tabular}

Los porcentajes y los totales se basen en los encuestados.

Our work presents some limitations, such as the design itself, since it is exposed to professionals wanting to respond, although it was done in a single day, there may be a memory bias on the part of the professionals, on the other hand, although the rate of response was low, can be considered within the expected (10-20\% of responses) not all questions were answered by all professionals. Recently Higueras et al28 published a work done in the Canary Islands with participation rates higher than ours (28.6\%).

Several studies give somewhat higher figures than ours in the relationship between administrative tasks and clinical care work, between 30 and $40 \%$ of the professional's work time is dedicated to purely bureaucratic tasks [29], often induced by other levels of care or by Other State, regional or local administrations On the other hand, postmenopausal osteoporosis has been associated with a high degree of underdiagnosis (up to 50\%).

In the DAPME Study [30], data are very close to those collected here, with figures showing $6 \%$ of patients with osteoporosis as a base disease in elderly people attended by the geriatrician or by the Primary Care physician and $4.2 \%$ as an associated disease.

The average age of the patients attended by OPM in APS is 67 years, although there is a great variability, having included in the study young patients, in the age group of 30 to 40 years. The majority of patients are in the range of 55-96 years. Age older than 65 years is considered a risk factor $(\mathrm{RR}>2)$ of fragility fracture [14], so that a large number of patients treated have a high risk of fracture.
The relationship between low BMI and the risk of osteoporotic fracture is well studied. A BMI of $20 \mathrm{Kg} / \mathrm{m}^{2}$ doubles the risk of osteoporotic fracture twice compared to patients with a BMI of 25 $\mathrm{Kg} / \mathrm{m}[14,27,31,32]$.

One in eight patients included in the study are new diagnoses. This data is somewhat larger than expected, and could be subject to a recall bias on the part of the doctor, that is, the participant could better remember the new case by calling more attention or having left more imprint than others already known.

The reference test for the diagnosis and evolutionary control of osteoporosis is the densitometry performed on the central skeleton (spine and hip) [9]. In 90\% of the cases of new diagnosis of our study, bone densitometry was performed.

In our study, physicians performed OPM Dx radiologically, several authors have shown that radiological studies should not be used for the diagnosis of osteoporosis20. In cases of osteopenia, its sensitivity and specificity are not all that is desirable, since it varies according to different physical parameters as well as the subjective opinion and experience of the interpreter, since there must be a loss of $20-40 \%$ in bone mass for osteopenia to be detected radiologically [9].

Osteoarthritis and low back pain, followed by back pain and rheumatoid arthritis, are the main associated comorbidities of the locomotor system to OPM, while the main causes of comorbidity that do not affect the locomotor system are hypertension, depression, anxiety and diabetes. There is a description of the association of depression 
with bone loss and osteoporotic fractures due to specific endocrine and immune mechanisms [33].

It is recommended to perform physical exercise [1,9] day for 30 minutes, at least, 3 times a week. The doctors in our study recommend it regularly, while eliminating tobacco and alcohol consumption.

Our study coincides with that published by Carbonel et al. [34] and Higueras et al. [28] in the sense that patients receiving bisphosphonate treatments receive a pharmacological supplement with calcium and vitamin $\mathrm{D}$, although there is a high number of patients who are not prescribed, also We observe that in many cases it is the PC physicians who initiate the treatments, based on the data that exists in the clinical history, similar to that published by De Felipe et al. [7].

Pharmacological treatment should be based on the individual assessment of the patient, according to their risk of fracture, taking into account the bone mass, other risk factors for osteoporosis and fracture, therapeutic compliance, life expectancy and the opinion of the patient [35].

The main sources of evidence used by the physicians of APS who have participated in the study are the Clinical Practice Guidelines in three out of four cases, followed by the Action Protocols, Specialist Recommendations and Consensuses and Documents of Scientific Societies.

More than three out of four doctors prefer the cost-effectiveness and not the price or cost of day treatment as a parameter to evaluate the cost of OPM treatment.

The main sources of evidence used by PHC physicians who have participated in the study are the Clinical Practice Guidelines in three of each four cases, followed by the Action Protocols, the Recommendations of the Specialist and the Consensus and Documents of $S$ scientific societies.

\section{Conclusions}

There is a high rate of therapeutic noncompliance, which makes the lack of therapeutic adherence in one of the three vertices.

In the light of the results obtained, the need arises to perfect the knowledge and improve the skills of physicians. PHC in the care of patients with OPM, through specific information and training programs based on diagnostic, therapeutic and follow-up decision algorithms, based on scientific evidence and the handling of specific clinical cases, given the high comorbidity of these patients and, therefore, the need to approach the patient and not the disease.

\section{Ethical aspects}

This study was carried out after receiving the Approval by the Committee of Ethics Research with Medication (CEIM) of Hospital Insular Maternal and Child University Complex (CHUIMI), held in ordinary session on February 27, 2014.

\section{Conflicts of interest}

The authors declare that they have no conflicts of interest.

\section{Acknowledgments}

To Dr. José María Limiñana for his support in carrying out the statistical part of this study. A Sesfordep_SEFyp (Spanish Society of Education for health, training and professional development), the Managers of Primary Care of the Health Area of Gran Canaria and
Tenerife, the General Directorate of Assistance Programs of the SCS, the Directors of Areas de Salud from La Palma, El Hierro, La Gomera, Lanzarote and Fuerteventura, the presidents of SoCaMFyC and Semergen and of course all those colleagues who answered us. Finally to Dr. Manuel Sosa, for his scientific contributions.

\section{References}

1. Martínez D, Abad P, Orero A, Navarro A, Olmo V González J, et al. (2018) Estudio Sociosanitario Osteoporosis Posmenopausica en Atención Primaria. Proyecto ESTOPMAP.

2. Carbonell Abella C (2011) La osteoporosis en atención primaria. Rev Osteopor Metab Miner 3: 73-74.

3. Naranjo A, Rosas J, Ojeda S, Salas E, el grupo canal (2013) Manejo de la osteoporosis en Atención primaria antes y después del resultado de la densitometría: tratamiento Instaurado versus Tratamiento recomendado en los consensos (Estudio CANAL). Reumatol Clin 9: 269-273.

4. Dirección General de Farmacia y Productos Sanitarios. Recomendaciones para la valoración y tratamiento de la osteoporosis primaria en mujeresde la Comunidad de Madrid. Madrid: Comunidad de Madrid, Consejería de Sanidad; 2007.

5. [No authors listed] (2001) NIH Consensus Development Panel on Osteoporosis Prevention Diagnosis and Therapy. Osteoporosis prevention, diagnosis, and therapy. JAMA 285: 785-995. [Crossref]

6. Reginster JY, Burlet N (2006) Osteoporosis: a still increasing prevalence. Bone 38 S4-S9. [Crossref]

7. De Felipe R, Cáceres C, Cimas M, Dávila G, Fernández S, et al. (2010) Características clínicas de los pacientes con tratamiento para la osteoporosis en un centro de Atención Primaria: ¿a quién tratamos en nuestras consultas? Aten Primaria 42: 559-563.

8. Toquero de la Torre, Rodríguez Sandin F, Noguéz Solán X, Carbonel Abella C, Martín Jíménez JA, et al. (2008). Guía de Buena Práctica Clínica en OSTEOPOROSIS. OMC and Ministerio de Sanidad y Consumo. Internattinal Marketing and Comunication.

9. González Macías J, Del Pino Montes J, Olmos JM, Nogués X, (2015) Guías De Práctica Clínica En La Osteoporosis Posmenopáusica, Glucocorticoidea Y Del Varón. Sociedad Española De Investigación Ósea Y Del Metabolismo Mineral. Rev Clin Esp 215: 515-526.

10. Adami S, Bianchi G, Brandi ML, Di Munno O, Frediani B, et al. (2010) Validation and further development of the WHO 10-year fracture risk assessment tool in Italian postmenopausal women: project rationale and description. Clin Exp Rheumatol 28: 561-570.

11. Gómez de Tejada Romero MJ, Sosa Henríquez M (2014) Osteoporosis: definición tendencia epidemiológica avances en la fisiopatologías y clínica. Medicine 11: 35273534.

12. Azagra R, Roca G, Martín Sánchez JC, Casado E, Encabo G, et al. (2014) Umbrales de FRAX para identificar personas con alto riesgo de fractura osteoporóticas en poblacion femenna española. Med Clin Barc.

13. O’Neill TW, Felsenberg D, Varlow J, Cooper C, Kanis JA, et al. (1996) The prevalence of vertebral deformity in european men and women: the European Vertebral Osteoporosis Study. J Bone Miner Res 11: 1010-1018. [Crossref]

14. Ministerio de Sanidad and Política Social e Igualdad. Guía de Práctica Clínica sobre Osteoporosis y Prevención de Fracturas por Fragilidad. Ministerio de Ciencia e Innovación. 2010. Barcelona, Ministerio de Ciencia e Innovación.

15. Hawkins Carranza F, Martinez Día Guerra G (2007) Nuevas estrategias terapéuticas en la osteoporosis. Endocrinol Nutr $54: 420-431$.

16. Hopkins RB, Goeree R, Pullenayegum E, Adachi JD, Papaioannou A, et al. (2011) The relative efficacy of nine osteoporosis medications for reducing the rate of fractures in post-menopausal women. BMC Musculoskelet Disord 12: 209. [Crossref]

17. Pérez-López FR (207) Vitamin D and its implications for musculoskeletal health in women: an update. Maturitas 58: 117-137. [Crossref]

18. Bolland MJ, Grey A, Avenell A, Gamble GD, Reid IR (2011) Calcium supplements with or without vitamin D and risk of cardiovascular events: reanalysis of the Women's Health Initiative limited access dataset and meta-analysis. BMJ 342: d2040. [Crossref]

19. Blanch J, Casado E, González J, Valdés C Ruiz-Baena J, Palomino J, et al. (2016) Percepcion de los profesionales médicos respecto la adherencia terapéutica de los pacientes con osteoporosis. Rev osteoporosis Metab Miner 8:15-23. 
20. Pérez Edo L, Alonso Ruíz A, Roig Vilaseca D, Garcia Vadillo A, Guañabens Gay N, et al. (2011) Actualizacion 2011 del consenso sociedad Española de Reumatologia de Osteoporosis. Reumatol clin 7: 357-379.

21. Guía de práctica clínica sobre osteoporosis. Madrid Grupo de estudio e invetsigacion de la osteoporosis. Sociedad Española de Cirugia Ortopedica y Traumatología (SECOT): 2010.

22. Scottish Intercollegiate Guidelines Network (SIGN). Management of osteoporosis and the prevention of fragility fractures. Edinburgh: SIGN; 2015. (SIGN publication no. 142). [March 2015].

23. Cosman F, de Beur SJ, Leboff MS, Lewiecki EM, Tanner B, et al. (2014) Clinician`s guide to Prevention and treatment of osteoporosis. National Osteoporosis Foundation (NOF). Osteopor Int 25: 2359-2381. [Crossref]

24. Watts NB, Bilezikian JP, Camacho PM, Greenspan SL, Harris ST, et al. (2010) American Association of Clinical Endocrinologists Medical Guidelines for Clinical Practice for the diagnosis and treatment of postmenopausal osteoporosis. Endocr Pract 16 (Suppl 3): 1-37. [Crossref]

25. [No authors listed] (2010) Management of osteoporosis in postmenopausal women: 2010 position statement of The North American Menopause Society. Menopause 17: 25-54.

26. National Institute for Health and Clinical Excellence (NICE). Alendronate, etidronate, risedronate, raloxifene, strontium ranelate and teriparatide for the secondary prevention of osteoporotic fragility fractures in postmenopausal women (amended). En: NICE technology appraisal guidance 161. London: National Institute for Health and Clinical Excellence; 2011.

27. Kanis JA, Burlet N, Cooper C, Cooper C, Rizzoli R, et al. (2008) European guidance for the diagnosis and management of osteoporosis in postmenopausal women. Osteoporos Int 19: 399-428. [Crossref]
28. Higueras Linares T, Sosa cabrera N, Blanco Blanco J, Fernédez palacio LM, Sosa Henriquez M (2014) Conocimeinto de la osteoporosis y gatso faramcéutico Generado en Atención Primari en las Isals Canarias. Rev Osteoporos Metb Miner 6: 89-96.

29. Pedrera V, Gil V, Orozco D, Prieto I, Schwarz G, et al. (2005) Características de la demanda sanitaria en las consultas de medicina de familia de un área de salud de la Comunidad Valenciana. Aten Primaria 35: 82-88.

30. Martinez D, Gil P, Orero A, Rodríguez de la Pinta ML, González J, Carabantes D, et al. (2012) J. M. Proyecto DAPME. Un día en Atención Preventiva al paciente mayor en España. 2012. Madrid, SESFORDEP, SEGG.

31. de Laet C, Kanis JA, Odén A, Johanson H, Johnell O, et al. (2005) Body mass index as a predictor of fracture risk: A meta-analysis. Osteoporos Int 16: 1330-1338.

32. Compston J, Cooper A, Cooper C, Francis RM, Kanis JA, National Oseoporosis Guideline Group (2010) Guideline for the diagnosis and management of osteoporosis in postmenopausal women and men from the age of 50 years in the UK. Maturitas 62 : 105-108. [Crossref]

33. Cizza G (2011) Major depressive disorder is a risk factor for low bone mass, central obesity, and other medical conditions. Dialogues Clin Neurosci 13: 73-87. [Crossref]

34. Carbonell C, Diez A, Calaf J, Caloto MT, Nocea G, et al. (2012) Pauta de tratamiento inicial en pacientes con osyteoporosis; uso de antirresortivos y suplementos farmacologicos (calcio y Vitamina D) en la practica clínica. Reumatol Clin 8: 3-9.

35. Carraco E, Gávez J, Hidalgo IM, Linares LF, Marín P, Marras C, et al. (2002) Recomendaciones para el manejo de la osteoporosis en Atención Primaria. Murcia, SEMERGEN-MURCIA, SEGO, SMR.

Copyright: (C)2018 Olmo Quintana V. This is an open-access article distributed under the terms of the Creative Commons Attribution License, which permits unrestricted use, distribution, and reproduction in any medium, provided the original author and source are credited. 